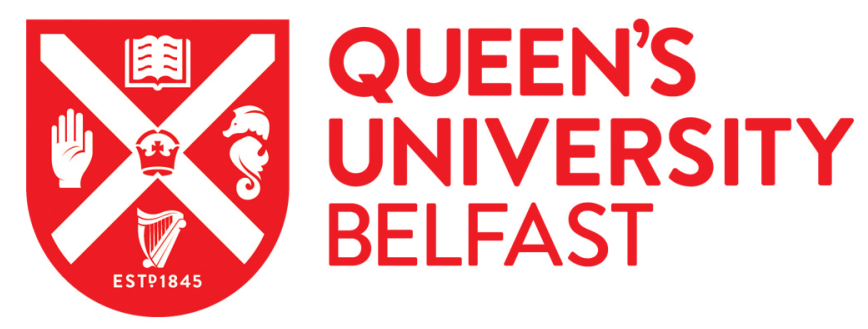

\title{
Politics and Gender on the Island of Ireland: the Quest for Political Agency
}

Galligan, Y., \& Buckley, F. (2013). Politics and Gender on the Island of Ireland: the Quest for Political Agency. Irish Political Studies, 28(3), 315-321. https://doi.org/10.1080/07907184.2013.826192

Published in:

Irish Political Studies

Document Version:

Peer reviewed version

Queen's University Belfast - Research Portal:

Link to publication record in Queen's University Belfast Research Portal

\section{Publisher rights}

Copyright 2013 Political Studies Association of Ireland.

This is an Accepted Manuscript of an article published by Taylor \& Francis in Irish Political Studies on 10 Sept 2013, available online: http://wwww.tandfonline.com/10.1080/07907184.2013.826192.

\section{General rights}

Copyright for the publications made accessible via the Queen's University Belfast Research Portal is retained by the author(s) and / or other copyright owners and it is a condition of accessing these publications that users recognise and abide by the legal requirements associated with these rights.

Take down policy

The Research Portal is Queen's institutional repository that provides access to Queen's research output. Every effort has been made to ensure that content in the Research Portal does not infringe any person's rights, or applicable UK laws. If you discover content in the Research Portal that you believe breaches copyright or violates any law, please contact openaccess@qub.ac.uk. 


\section{Politics and Gender on the Island of Ireland: The Quest for Political Agency}

\section{FIONA BUCKLEY* and YVONNE GALLIGAN**}

*Department of Government, University College Cork, Cork, Ireland.

** School of Politics, International Studies and Philosophy, Queen's University Belfast, Belfast, Northern Ireland.

\section{Introduction}

Women's political agency is not a recent phenomenon in Ireland. As a decade of historical commemorations on the island gets underway, we are reminded of the efforts of women's rights campaigners during that time. 'For men and women equally the rights of citizenship; from men and women equally the duties of citizenship' declared Isabella Tod, unionist and feminist, in 1875 . Tod's words were an inspiration and a guiding principle for feminist activists in Ireland in the late $19^{\text {th }}$ and early $20^{\text {th }}$ centuries. The power of female collective agency at that time brought about votes for women. Tod and her compatriots believed that this fundamental citizenship right would enable women take their rightful place alongside men in public affairs. A century on, the quest for formal and substantive gender equality continues. Politics and Gender on the Island of Ireland: The Quest for Political Agency brings together a collection of articles concerned with uncovering the marginalised experiences of women in modern politics on the island of Ireland and details recent efforts to challenge the masculinised status quo. The term 'political agency' refers to the extent to which women feel enabled to make claims upon democratic politics, the state and political institutions and in doing so, shape political outcomes. There are a number of sites in which women as institutional and extra-institutional actors today search for greater recognition of their claims to representation, equality and human rights, notably political parties, parliament, executives, courts and civil society. In exploring the relationship between women, the state and democratic politics on the island of Ireland today, 'gender' is treated as a category of analysis and a process of change. Understanding

Correspondence Address: Fiona Buckley, Department of Government, O'Rahilly Building, University College Cork, Cork, Ireland. Email: f.buckley@ucc.ie; Yvonne Galligan, School of Politics, International Studies and Philosophy, Queen's University Belfast, University Road, Belfast BT7 1NN, Northern Ireland. Email: y.galligan@qub.ac.uk. 
gender as a category recognises that organisations institutionalise definitions of masculinity, constructing gender cultures and defining gender appropriate jobs that reflect and advance masculine norms. Feminine actors, usually (but not always) women, can find themselves being marginalised and pigeonholed into 'female appropriate' roles, and employ their agency to wrestle within and against institutional norms for acceptance and advancement. Understanding gender as a process suggests not only are institutions and politics gendered, but they can be gendered (Beckwith, 2005: 132). In other words, female political agency, through the activities of politicians, civil society and feminist actors, can work to establish practices and rules that recast and re-inscribe the gendered foundations of democratic politics, political institutions, and the state. Exploring the potential, and limitations, of modern female political agency on the island of Ireland is the focus of this issue.

\section{The quest for political agency: an overview}

The electoral system is at the heart of any democracy, and the issue leads with a close feminist analysis by Claire McGing (2013) of the effects of the single transferable vote (STV) electoral system shared by the two political systems on the island. She comments upon the gendered nature of candidate selection processes on the island of Ireland and its effects on women's political representation. Considering the 2011 elections, she finds that electorates on either side of the border, all else considered, do not differentiate between candidate sex. She argues that a 'mismatch' exists between formal and informal factors influencing female candidacy and seat-holding in Dáil Éireann and the Northern Ireland Legislative Assembly. While the workings of STV are mostly 'women-friendly', political parties, especially those with higher levels of party magnitude, are reluctant to nominate women and men on more equal terms. This findings offer a challenge to the often repeated orthodoxy that parties are willing to 'experiment' and select more women candidates in districts with a high number of seats. Considerable levels of variation between parties in their propensity to advance their

Correspondence Address: Fiona Buckley, Department of Government, O'Rahilly Building, University College Cork, Cork, Ireland. Email: f.buckley@ucc.ie; Yvonne Galligan, School of Politics, International Studies and Philosophy, Queen's University Belfast, University Road, Belfast BT7 1NN, Northern Ireland. Email: y.galligan@qub.ac.uk. 
card-carrying women members suggest internal party cultures, and the ways in which specific party selectorates utilise the opportunities of the electoral system, are hugely important in helping or hindering women's advancement in politics. McGing advises that the key to achieving a 'critical mass' of women TDs and MLAs lies in reforming internal party selection processes to better accommodate equality between the sexes.

McGing's study is complemented by that of Fiona Buckley (2013) who reviews the role of women in political parties in Ireland since the 1990s and analyses party efforts to advance women in electoral politics. Her article shows that across all parties, women account for a much higher percentage of those in supportive roles (i.e. secretaries and treasurers) than in leadership positions (i.e. chairs and vice-chairs) concurring with earlier research, notably Galligan (2009), that finds a bias in favour of traditional gender roles in internal party structures. The article also shows that political parties have adopted a range of strategies, in line with their ideological orientation, to address women's political under-representation. For the most part, these strategies have been rhetorical and promotional in nature, and have not resulted in significant gains for women in electoral politics. All parties stopped short of voluntarily introducing more interventionist measures, such as guarantees or sex quotas, preferring merit as a basis of candidate selection. However, as highlighted by Buckley, meritorious arguments often ignore the many gendered barriers that women experience when considering a career in politics. She reminds us that in 2011, women's income in Ireland was around 73 per cent of men's and more than half a million women were looking after the home/family compared with only 9,600 men. Quite simply, women party members often have less time and funds to devote to local bailiwick-building activities. In light of much party resistance to quotas, the article then considers the current and seemingly contradictory cross party support for the adoption of legislative candidate sex quotas by the Irish Parliament in July 2012 and begs the question: what conditions came about, and

Correspondence Address: Fiona Buckley, Department of Government, O'Rahilly Building, University College Cork, Cork, Ireland. Email: f.buckley@ucc.ie; Yvonne Galligan, School of Politics, International Studies and Philosophy, Queen's University Belfast, University Road, Belfast BT7 1NN, Northern Ireland. Email: y.galligan@qub.ac.uk. 
were hitherto absent, that facilitated the introduction of candidate selection legislation? The article finds that the coming together of a constellation of pressures, notably a political reform discourse, the mobilisation of female collective agency through civic society groups, and elite support of the issue as a vehicle for projecting a reforming image, facilitated the introduction and adoption of legislation on candidate sex quotas.

The embedding of male-gendered norms in political institutions, and the consequences for women political representatives is examined by Eileen Connolly (2013) through the case of the Irish parliament (Oireachtas). In path-breaking work, Connolly scrutinises the gendered pattern of portfolio allocation in leadership roles (cabinet ministers, ministers of state and parliamentary committee chairs) from the late 1970s to 2012 . Her research reveals the extent to which the political leadership roles allocated to women have been clustered into a narrow band of portfolio areas that are commensurate with worldviews that assigns caring and nurturing roles to women. Contrary to the international literature which suggests that this type of gender stereotyping has reduced over time, Connolly finds that the Irish case does not conform to this trend. In fact, since the end of the 1970s the Irish parliament has continually re-inscribed a degree of gender stereotyping that is higher than international norms. Rather surprisingly this stereotyping has deepened during the past decade, a decade that witnessed dramatic socioeconomic and cultural changes, evidenced by women's increasing economic and educational empowerment. Connolly suggests that the high level of gender stereotyping in parliamentary leadership positions is reflective of the masculine culture found in Irish political parties, illustrating the continuing barriers that exist for women politicians and also for those considering entering politics.

Ivana Bacik (2013) addresses the political relationship between women and the state through a feminist critique of the Irish Constitution, in particular by tracing developments in the law on abortion

Correspondence Address: Fiona Buckley, Department of Government, O'Rahilly Building, University College Cork, Cork, Ireland. Email: f.buckley@ucc.ie; Yvonne Galligan, School of Politics, International Studies and Philosophy, Queen's University Belfast, University Road, Belfast BT7 1NN, Northern Ireland. Email: y.galligan@qub.ac.uk. 
in the Republic of Ireland. Assessing the Constitution, Bacik notes that the gender biases evident within the text of the fundamental rights provisions as adopted in 1937 reflected the power of the Catholic Church, the prevailing attitudes to women and the general conservative culture of the time. That bias was further compounded by the passing of the eighth Amendment to the Constitution in 1983. This Amendment inserted Article 40.3.3 into the text and provides that the right to life of a pregnant woman is equal with that of the foetus she carries. Tracking developments in abortion law, in particular the $X$ and $C$ cases, and subsequent cases brought before the European Courts of Human Rights in 2010, Bacik notes that the agents of change have rested not in parliamentary and legislative settings, but rather in the courts and legal systems, augmented by civil society. Bacik advises 'feminists also need to win the argument for change in the political and legislative arena too'. While the Protection of Life during Pregnancy Bill, introduced into the Dáil in June 2013, will give effect to the $1992 X$ case judgment, allowing abortion in limited circumstances where the life of the mother is threatened by the continuation of a pregnancy, Bacik notes its enactment has been a long time coming. She also calls for legislation to establish a statutory framework within which other reproductive health services may be regulated rather than solely rely on judicial decisions to fill the legislative vacuum. The case study highlights the impact of conservative attitudes on policy, in particular how such attitudes can serve to stagnate the legislative process.

Maria Deiana's (2013) article quintessentially encapsulates the purpose of this special issue. Examining the consequences for women's citizenship in Northern Ireland in the post Good Friday/Belfast Agreement era, she offers a critique of the persistent gender cultures which serve to exclude women as well as highlighting the efforts of civil society to engender change. Deiana argues that despite the promises of inclusion and equality set out in the peace document, subsequent institutional arrangements and policy decisions have retained gendered exclusions and reasserted

Correspondence Address: Fiona Buckley, Department of Government, O'Rahilly Building, University College Cork, Cork, Ireland. Email: f.buckley@ucc.ie; Yvonne Galligan, School of Politics, International Studies and Philosophy, Queen's University Belfast, University Road, Belfast BT7 1NN, Northern Ireland. Email: y.galligan@qub.ac.uk. 
gender stereotypes. The political settlement has failed to fully address the gendered legacy of three decades of conflict and does not fulfil the democratic promises of advancing women's citizenship claims. However, Deiana notes that despite persisting constraints, women continue the pattern of active civic engagement in the community and voluntary sector and pursue lobbying strategies which strive to make their claims relevant in institutionalised policy-making spheres. Highlighting the recent emergence of the Belfast Feminist Network in particular, Deiana demonstrates how feminist grassroots activism can contribute to enhance women's citizenship in the broader cultural and social context of post Good Friday/Belfast Agreement Northern Ireland.

Yvonne Galligan (2013) continues the discussion of women's political agency in Northern Ireland by focusing on the challenges to women's descriptive and substantive political representation. Setting out four criteria by which to analyse the gendered nature of representative politics through the prism of gender justice - inclusion, accountability, transparency and recognition - she highlights how parties are out of step with voters on this issue. On all analyses, voters indicate a desire to see more women as political representatives, but most parties fail to deliver on this wish. Galligan charts the growing prominence of women in other fields of influence, and in economic life, since the Good Friday/Belfast Agreement and observes an increasing impatience among women in general with the male-dominated face of democratic politics. She details the nature of party selection practices and their gendered biases, while recognising that some movement is underway in internal party processes to address the representation gap. Galligan uses the collectively-produced Women's Manifesto, widely endorsed by women's civil society, as a measure against which she reviews party manifesto promises to women since 1998. Returning to the four criteria, she finds that gender justice is a variable component of party politics - those parties that rank high on recognition also do best on inclusion of women, along with

Correspondence Address: Fiona Buckley, Department of Government, O'Rahilly Building, University College Cork, Cork, Ireland. Email: f.buckley@ucc.ie; Yvonne Galligan, School of Politics, International Studies and Philosophy, Queen's University Belfast, University Road, Belfast BT7 1NN, Northern Ireland. Email: y.galligan@qub.ac.uk. 
internal and external accountability. For other parties, gender equality, and gender justice more broadly, is framed in a manner limiting to women's political agency.

Questions of multiculturalism, identity, integration and gender are the focus of Victoria Montgomery's (2013) article. Using the veil as a lens through which to explore narratives about identity in Northern Ireland and the Republic of Ireland, the article demonstrates the integration philosophies at work, and furthermore considers the wider gender implications of integration. Utilising fieldwork carried out with Muslim women in Ireland, Montgomery analyses the veil as a symbol of otherness in Ireland, as a symbol of the threat of diversity, and as a symbol of fundamentalism in 'secular' Ireland. Montgomery argues that the ethnic bases of Irishness have not been so undermined as to fully allow the recognition and inclusion of a veiled Muslim woman. The exclusive nature of Irishness has resulted in discrimination against those who do not assimilate or who seem to be too physically and culturally different from the majority. Montgomery also highlights the paradoxical relationship between officialdom and integration. While diversity is celebrated in Ireland, it does so by basing integration on assimilation. Pointedly, in Northern Ireland, diversity is rarely articulated beyond the Catholic/Protestant fault-line. The Good Friday/Belfast Agreement which has served as the catalyst for pushing an equality agenda does not mention minorities living in the province, yet, as noted by Montgomery, more than one fifth of the population does not belong to either the Protestant or Catholic tradition. In the Republic of Ireland, the equality sector has been severely affected by government funding cuts allowing racism to occur in the absence of monitoring bodies highlighting such incidents.

Finally, Melanie Hoewer (2013) presents a critique of the Irish and British government's continual avoidance of the implementation of UN Security Council Resolution (UNSCR) 1325 in Northern Ireland. Passed in October 2000, UNSCR 1325 was envisaged by the UN as a landmark document to protect

Correspondence Address: Fiona Buckley, Department of Government, O'Rahilly Building, University College Cork, Cork, Ireland. Email: f.buckley@ucc.ie; Yvonne Galligan, School of Politics, International Studies and Philosophy, Queen's University Belfast, University Road, Belfast BT7 1NN, Northern Ireland. Email: y.galligan@qub.ac.uk. 
women in the context of armed conflict and to involve them, and a gender perspective, in peacebuilding processes. Hoewer advises that UNSCR 1325 has yet to reach its full potential in application on the island of Ireland. While the Irish and British governments have implemented National Action Plans (NAP), these have been outward and international focused. Engagement in peace-building activities at home is more problematic with both governments continuing to avoid responsibility for the implementation of UNSCR 1325 in Northern Ireland. To date, women's perspectives and experiences of conflict from Northern Ireland have been largely excluded from existing Irish and British action plans. The Irish government's plan positions Northern Ireland outside the physical borders of the Irish state and the UK positions the region outside the scope of its National Action Plan, which emphasises the international peacekeeping aspects of policing and military operations. Similar to Deiana (2013), Hoewer's article serves a dual purpose of highlighting the continuing marginalisation of women's experiences in post Good Friday/Belfast agreement Northern Ireland while simultaneously drawing attention to women's activism in civil society, activism and lobbying which strives to present a gendered assessment in an all too male dominated peace process.

\section{Conclusion}

I think being a woman is like being Irish... Everyone says you're important and nice, but you take second place all the time (Iris Murdoch, The Red and the Green 1965: 30).

Iris Murdoch's words maybe dismissed for their acerbic anti-Irish undertones, but they carry strong echoes of truth when assessing the contemporary role of women in politics on the island of Ireland. Throughout this issue, the marginalised experiences of women are highlighted. What emerges from the articles is the commonality of women's struggle to make political claims in contexts that are politically different, but which share a deeply conservative understanding of equality. The reluctance to take a risk on running female candidates is shared by parties in both jurisdictions, as is the

Correspondence Address: Fiona Buckley, Department of Government, O'Rahilly Building, University College Cork, Cork, Ireland. Email: f.buckley@ucc.ie; Yvonne Galligan, School of Politics, International Studies and Philosophy, Queen's University Belfast, University Road, Belfast BT7 1NN, Northern Ireland. Email: y.galligan@qub.ac.uk. 
continuation of male-gendered institutional norms in legislatures and parties. In addition, a reluctance to recognise women as a political grouping and the invisibility of women's interests, perspectives and identities pervades the discussions. Yet, the articles also bear witness to female political empowerment, to a re-gendering of politics in some spheres, and to the vibrancy of women's civil society activities. Collectively, the articles point to the manner in which women's negotiations with democratic politics and the state are taking place, shedding new and original light on female political agency within and outside modern politics on the island of Ireland.

\section{References}

Bacik, I. (2013) The Constitution and Gender Politics: Developments in the Law on Abortion, Irish Political Studies, 28 (3), pp.

Beckwith, K. (2005) A common language of gender? Politics \& Gender, 1(1), pp. 128-137

Buckley, F. (2013) Women and Politics in the Republic of Ireland: The Road to Sex Quotas, Irish Political Studies, 28 (3), pp.

Connolly, E. (2013) Parliaments as Gendered Institutions: The Irish Oireachtas, Irish Political Studies, $28(3), \mathrm{pp}$.

Deiana, M. (2013) Women's Citizenship in Northern Ireland after the 1998 Agreement, Irish Political Studies, 28 (3), pp.

Galligan, Y. (2009) Women in politics, In: J. Coakley and M. Gallagher (Eds.), Politics in the Republic of Ireland, pp. 263 - 291, (London: Routledge/PSAI Press).

Galligan, Y. (2013) Gender and Politics in Northern Ireland: the representation gap revisited, Irish Political Studies, 28 (3), pp.

Hoewer. M. (2013) UN Resolution 1325 in Ireland: Limitations and Opportunities of the International Framework on Women, Peace and Security, Irish Political Studies, 28 (3), pp.

McGing, C. (2013) The Single Transferable Vote (STV) and Women's Representation in Ireland, Irish Political Studies, 28 (3), pp.

Montgomery, V. (2013) Multicultural Ireland? Muslim Women and Integration in Ireland, Irish Political Studies, 28 (3), pp.

Correspondence Address: Fiona Buckley, Department of Government, O'Rahilly Building, University College Cork, Cork, Ireland. Email: f.buckley@ucc.ie; Yvonne Galligan, School of Politics, International Studies and Philosophy, Queen's University Belfast, University Road, Belfast BT7 1NN, Northern Ireland. Email: y.galligan@qub.ac.uk. 
Correspondence Address: Fiona Buckley, Department of Government, O'Rahilly Building, University College Cork, Cork, Ireland. Email: f.buckley@ucc.ie; Yvonne Galligan, School of Politics, International Studies and Philosophy, Queen's University Belfast, University Road, Belfast BT7 1NN, Northern Ireland. Email: y.galligan@qub.ac.uk. 
Article 826193

Corrected Figures and Tables

Figure 1 Devolution and women's representation

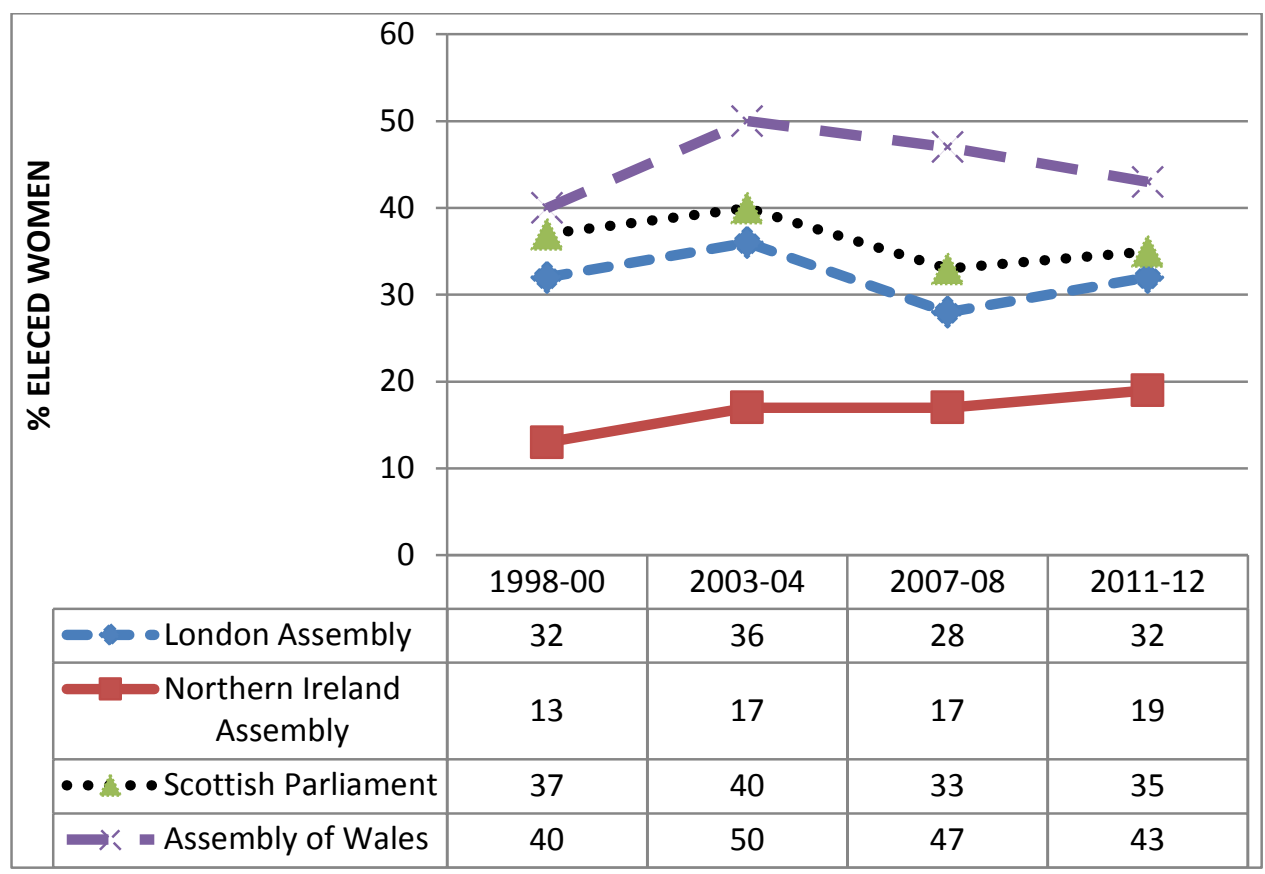

Figure 2 Women in Local Councils, Northern Ireland 1989-2011

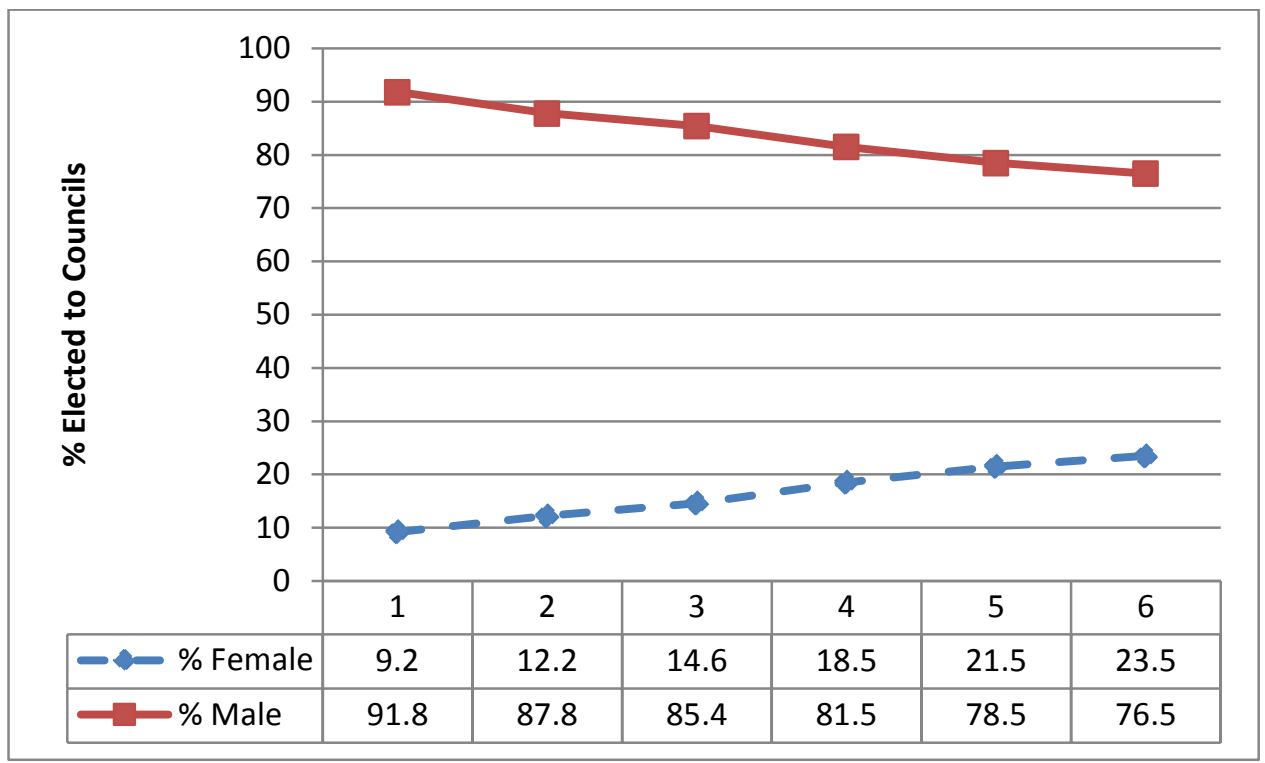


Table 1 Candidates and MLAs in the 2011 Election to the Northern Ireland Assembly, by sex

\begin{tabular}{|c|c|c|c|c|c|c|}
\hline \multirow[t]{2}{*}{ Party } & \multicolumn{2}{|c|}{ Candidates } & \multicolumn{2}{|c|}{ MLAs } & \multirow{2}{*}{$\begin{array}{l}\text { Women's } \\
\text { Rate of } \\
\text { Return } \\
\text { (\%) }\end{array}$} & \multirow{2}{*}{$\begin{array}{l}\text { Men's } \\
\text { Rate of } \\
\text { Return } \\
\text { (\%) }\end{array}$} \\
\hline & $\begin{array}{c}\text { Women } \\
\mathrm{N}(\%)\end{array}$ & $\begin{array}{l}\text { Men } \\
\text { N (\%) }\end{array}$ & $\begin{array}{c}\text { Women } \\
\mathrm{N}(\%)\end{array}$ & $\begin{array}{l}\text { Men } \\
\mathrm{N}(\%)\end{array}$ & & \\
\hline APNI & $7(30)$ & $16(70)$ & $2(25)$ & $6(75)$ & 29 & 38 \\
\hline DUP & $7(16)$ & 37 (84) & $5(13)$ & $33(87)$ & 71 & 89 \\
\hline SDLP & $4(14)$ & 24 (86) & $3(21)$ & $11(79)$ & 75 & 46 \\
\hline SF & $11(28)$ & $29(72)$ & $8(28)$ & $21(72)$ & 73 & 72 \\
\hline UUP & $3(10)$ & $26(90)$ & $2(13)$ & $14(87)$ & 67 & 54 \\
\hline Other & $6(11)$ & 49 (89) & 0 & $3(100)$ & 0 & 100 \\
\hline Total & 38 (17) & $181(83)$ & 20 (19) & $88(81)$ & 53 & 49 \\
\hline
\end{tabular}

Table 2 Average candidate votes in 2011 Assembly election, by sex

\begin{tabular}{|l|c|c|c|}
\hline Party & Male & Female & $\begin{array}{c}\text { Average vote } \\
\text { Difference }\end{array}$ \\
\hline APNI & 2197 & 2560 & 363 \\
\hline DUP & 4664 & 4205 & -459 \\
\hline SDLP & 3205 & 4169 & 964 \\
\hline SF & 4370 & 4681 & 311 \\
\hline UUP & 2953 & 3879 & 926 \\
\hline Average & 3477.8 & 3898.8 & 421 \\
\hline
\end{tabular}

